\title{
Changes on Selected Hydrologic Regimes in Southeast Blue Nile River Basin: The Case of Neshe Watershed, Ethiopia
}

\author{
Sisay Mekonnen \\ Assosa University, College of Agriculture and Natural Resources, \\ Department of Soil and Water Resource Management
}

\begin{abstract}
Variability of hydrologic regimes is the major indicators of change in the climatic condition of the area. Hence, a good understanding on the changes of hydrologic regime is crucial for sustainable water resources management. However, investigations on such relationships are little in Ethiopia both at national and watershed scale. Therefore, this study was designed to deal with the change in rainfall and stream flow pattern of Neshe watershed for the period of 33 years (1972-2005) in South-East Blue Nile Basin, Ethiopia. The hydrologic data were obtained from Ethiopian Ministry of water resource and National Meteorological agency. Statistical correlation and linear regression analysis was used to detect the periodic trends of the change in the selected hydrologic regimes. Trend analysis for the period 1972 to 1986 has revealed insignificant seasonal variation in the total flow and annual rainfall $(\mathrm{p}>0.05)$. However, dry season base flow and mean annual peak flow were significantly reduced. For the period 1987 to 2005, total flow showed a noticeable increasing trend in the wet season and a decreasing trend in its dry season flow while; base flow in the wet season, annual peak flow and rainfall were not considerably varied. But an imperative dry season decreasing trend was observed on the base flow. Even though, seasonal and periodic variations in terms of increase or decrease for the whole considered hydrologic variables were observed, the overall (1972 to 2005) time series analysis on the hydrologic variable revealed that rainfall and stream flow show a significant increasing trend in rainfall; total flow and peak flow components while a decreasing trend in base flow. Therefore, it is concluded that the study shows the annual variation in water yield potential of Neshe watershed.

Keywords: watershed, hydrology, total flow, peak flow, base flow, rainfall
\end{abstract}

DOI: $10.7176 / \mathrm{JEES} / 9-2-05$

\section{Introduction}

Currently, suspicions are increasing that the quality, quantity and flow regularity of streams in downstream areas are under serious threat than any time due to extensive land use/ land cover changes in the upstream areas (Jeans et al., 2006). These issues pressurize the hydrological resources to be the recently recognized conservation and monitoring priority in global condition.

The rainfall and water resources distribution of the country is variable both in time and space. For instance, the central, western and south western parts are blessed with ample water resources, while most of North Eastern and Eastern parts of the country are relatively dry. Hence, despite abundance in some parts, the country is highly water-scarce due to lack of water control infrastructure (Seleshi et al., 2007). Other literatures also indicated that the direction of land cover change impacts on flow regimes, let alone its magnitude but also challenges a simple generalization especially with regard to flow extremes (Woldeamlak, 2003; Gebrehiwot et al., 2010; Legesse et al., 2003).

Furthermore, land degradation in addition is a major reason for silting of dams and riverbeds, increasing irregularity of streams and rivers and reduced groundwater capacity (Leonard, 2003). This study was designed in order to examine the seasonal and periodic trends of rainfall, peak flow, total flow and base flow patterns at Neshe Watershed, South-East Blue Nile Basin, Ethiopia.

\section{Materials and Methods}

\subsection{Description of the study area}

\subsubsection{Geographic location}

According to Awulachew et al. (2008) and Abbay River Basin Integrated Development Master Plan Project (ARBIDMPP, 1998), the Abbay river basin in Ethiopia is divided into 16 reasonably homogeneous areas named basin units or sub basins, representing each the catchment of one tributary or of several minor ones with similar behavior. Out of these Finchaa sub basin from the south eastern part is the one to which this study was carried out. This area is selected based on the accessibility of data for more than 30 years and since the watershed is sought to be one of the potential future development areas where currently some water resources development projects like Finchaa multipurpose hydropower project and Finchaa sugar farm Irrigation projects are in progress. In addition to these issues, Neshe hydropower dam construction is the ongoing water resources development related project specific to the study site. Moreover, information concerning to this basin as one of sub basin that contributes water to the Blue Nile River helps to know the rainfall and flow variability related with land cover change status from the upstream area. 
Specifically, the study was carried out in Neshe watershed under Finchaa sub basin of Blue Nile, Horro Gudurru Wollega Zone in west central Ethiopia having a drainage area about $336 \mathrm{~km}^{2}$. The area is bounded by escarpments from east, west and north within the general boundaries of latitudes $9^{\circ} 30^{\prime} \mathrm{N}$ to $9^{\circ} 45^{\prime} \mathrm{N}$ and longitudes $37^{\circ} 15^{\prime}$ to $37^{\circ} 30^{\prime} \mathrm{E}$ at an altitude between $2,588 \mathrm{~m}$ and $2,202 \mathrm{~m}$ above sea level at about $312 \mathrm{~km}$ north-west of Addis Ababa. The area can be reached following the main highway from Addis Ababa to Gedo (192Km west of Addis Ababa) and thereafter by means of an all weather gravel road from Gedo via Finchaa Dam, 95km $+25 \mathrm{~km}$ from Gedo in the Northwest direction (Bayissa, 2007).

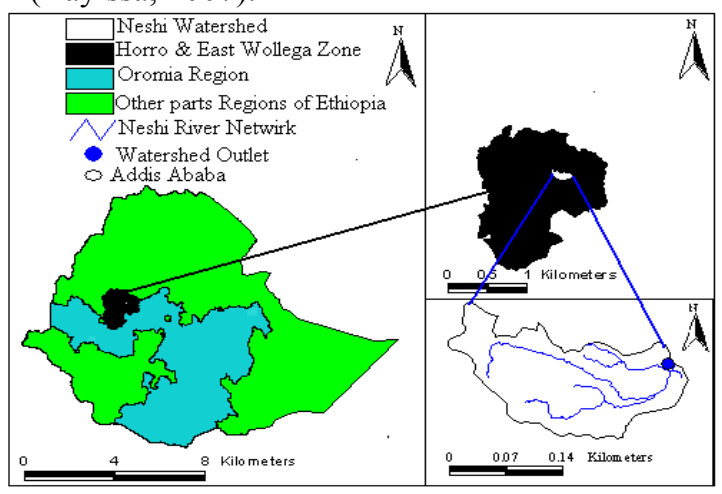

Figure 1: Map of the study area

\subsubsection{Climate and hydrology}

The study area is typically characterized by Wet Weyna Dega climatic region in Ethiopian traditional agro climatic classification system having one long rainy season, from May upto October depicting a uni-modal rainfall characteristic (Figure 3).

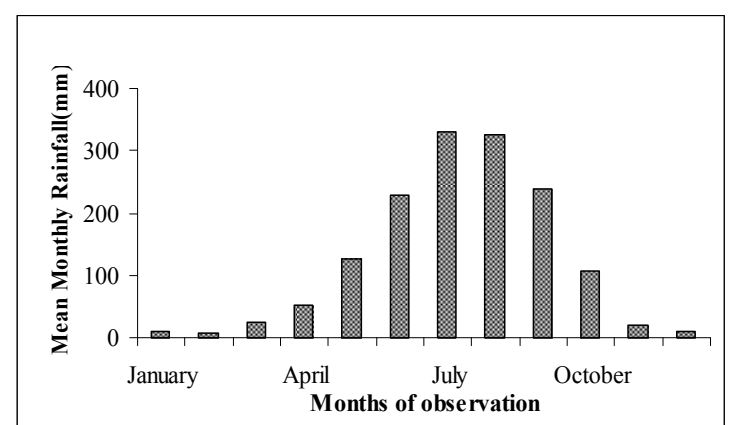

Figure 2: Mean Monthly Rainfall Distribution of the area for 1972 to 2005 period

The mean annual rainfall in the area amounts about $1,479.1 \mathrm{~mm}$ while the mean maximum and mean minimum temperatures are $30.6 \mathrm{C}^{\circ}$ and $14.5 \mathrm{C}^{\circ}$, respectively. Together with the undulating topographic nature, a network of seasonal streams heavily dissects the area. During the wet season, several temporary collections of surface waters of various sizes and durations are observed.

\subsubsection{Geology, Topography and soil types}

Geologically, Neshi watershed is dominated by Adigrat sandstone geologic formation which is resulted from the incursion of the area by water and sediment accumulation following the withdrawal of the water. Some areas around the middle and lower stream parts are originated from volcanic related basalts and Alluvium deposits respectively. The area is characterized by undulating topographic nature. The upstream areas of the watershed are mainly dominated by hills with steep slope while the downstream parts are plain with gentle slope.

\section{Result and Discussion}

\subsection{Analysis of the change in Rainfall and Stream flow}

In dealing with the changes in hydrological variables, it is important to distinguish the hydrologic regimes i.e. the distribution pattern of rainfall and stream flow types. Therefore, descriptive statistical parameters for the period 1972 to 2005 were extracted from the hydrologic data of the area in order to differentiate dry and wet patterns of the area. February is the driest month having $8.4 \mathrm{~mm}$ mean monthly rainfall, while July is the wettest one with $331.4 \mathrm{~mm}$ rainfall throughout the study period.

The largest year-to-year variation of rainfall was observed in February having coefficient of variation 199\%, whereas the lowest one was in July with $34 \%$ coefficient of variation. Based on the rainfall data, the wet season commences in May and extends until October though there are some fluctuations. The dry season of the area usually commences in November and extends up to April. Monthly rainfall totals of zero are a common occurrence during this dry season. 
Streamflow is lowest in February and March while reaches to its peak in August which means one month after the commencement of the wettest month. The year-to-year variations in streamflow are highest in October $(\mathrm{CV}=78.7 \%)$ while lowest in February having $(\mathrm{CV}=35.3 \%)$ coefficient of variation. The most important issue that arises from these simple observations of seasonal pattern is that the dry season stream flow originates overwhelmingly from the rain that has fallen in the preceding season. Though there are occasional showers during the dry season, the amount is insufficient to support the stream flow observed.

Table 1: Hydrologic Characteristics of Neshi Watershed for the period 1972 to 2005

\begin{tabular}{|c|c|c|c|c|c|c|c|c|c|c|c|c|c|}
\hline Parameters & Jan & $\overline{F b r}$ & Mar & April & May & June & July & $\overline{A u g}$ & Sep & Oct & Nov & Dec & Annual \\
\hline \multicolumn{14}{|c|}{ Rainfall (mm), $\%$ for $\mathrm{CV}$} \\
\hline Mean & 9.3 & 8.4 & 24.6 & 52.04 & 125.5 & 228.7 & 331.4 & 324.7 & 238.1 & 107.8 & 18.7 & 9.8 & 123.2 \\
\hline Min. & 0 & 0 & 0 & 0 & 1.5 & 81.7 & 111 & 89 & 0 & 0 & 0 & 0 & 0 \\
\hline Max. & 61.6 & 89.6 & 112.2 & 164.6 & 357.5 & 537.1 & 584.5 & 595 & 725.6 & 533.6 & 126.7 & 68.7 & 725.6 \\
\hline $\mathrm{CV}$ & 177.1 & 199.0 & 119.2 & 88.6 & 64.0 & 48.3 & 34.8 & 37.8 & 59.0 & 109.0 & 141.7 & 154.8 & 102.7 \\
\hline \multicolumn{14}{|c|}{ Streamflow (MCM)), $\%$ for CV } \\
\hline Mean & 1.4 & 0.8 & 0.8 & 0.7 & 1.5 & 5.3 & 35.2 & 63.7 & 50.5 & 24.7 & 5.2 & 2.2 & 16.04 \\
\hline Min. & 0.2 & 0.3 & 0.1 & 0.05 & 0.008 & 0.7 & 11.1 & 32.1 & 21.3 & 6.7 & 1.1 & 1.2 & 0.008 \\
\hline Max. & 2.7 & 1.6 & 2.2 & 1.8 & 3.1 & 16.1 & 105.4 & 139.1 & 114.6 & 106.7 & 14.7 & 5.6 & 139.18 \\
\hline $\mathrm{CV}$ & 37.8 & 35.3 & 47.8 & 57.2 & 53.0 & 66.8 & 64.36 & 38.2 & 43.2 & 78.7 & 64.5 & 52.4 & 53.27 \\
\hline
\end{tabular}

Note: Min. $=$ Minimum, Max. $=$ Maximum, $\mathrm{CV}=$ Coefficient of Variation

The annual and 3-years moving average graph of mean annual rainfall and total flow of the area shows a corresponding cyclic trend with a relative lower magnitude for the period 1972 to 1986 (Figure 3). This magnitude depicts an increasing trend for the period 1987 to 2005. Correspondence between mean annual rainfall and total flow is observed via a relatively smaller event for both parameters during 1970s and 1980s while an increasing trend after 1990s. The moving average slope of totalflow in the early period is gentle, indicating the occurrence of a bite constant trend during this period.

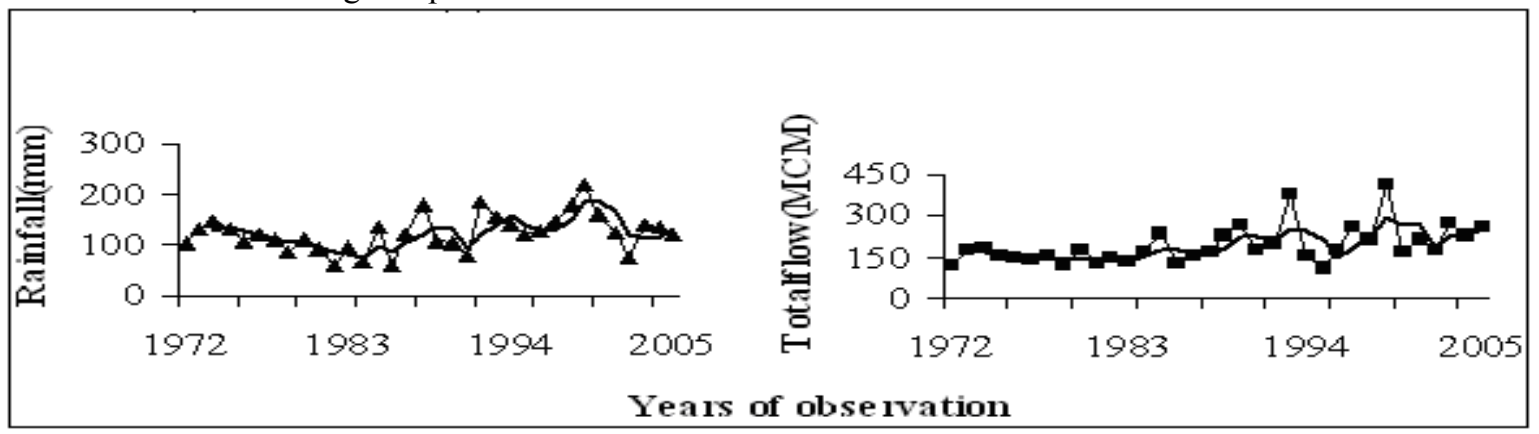

Figure 3: Cyclic observation by 3-years moving average for rainfall $\&$ total flow

3.3.1 Periodic change in mean annual rainfall and annual peak flow

Periodic variations of rainfall and peak flow as well as the seasonal variations of total flow and base flow components are graphically plotted (Figures 3 to 9) and the summary statistics of the result are shown in (Table 2). 
Table 2: Statistical analysis result for seasonal and periodic change observation on the hydrologic variables

\begin{tabular}{|c|c|c|c|c|}
\hline Periods & Seasons & Variables & \multicolumn{2}{|c|}{ Parameters } \\
\hline \multirow{4}{*}{$1972-1986$} & \multirow{3}{*}{ Wet } & & Slope & p-values \\
\hline & & Total flow & 0.445 & 0.720 \\
\hline & & Base flow & 1.131 & 0.071 \\
\hline & \multirow[t]{4}{*}{ Dry } & Total flow & 0.279 & 0.522 \\
\hline \multirow{9}{*}{$1987-2005$} & & Base flow & -0.058 & $0.005^{*}$ \\
\hline & & Annual peak flow & -0.263 & $0.009 *$ \\
\hline & & Mean annual rainfall & -3.509 & 0.121 \\
\hline & \multirow[t]{2}{*}{ Wet } & Total flow & 3.215 & $0.009^{*}$ \\
\hline & & Base flow & 1.099 & 0.060 \\
\hline & \multirow[t]{4}{*}{ Dry } & Total flow & -0.313 & $0.003 *$ \\
\hline & & Base flow & -0.215 & $0.004 *$ \\
\hline & & Annual peak flow & 0.764 & 0.228 \\
\hline & & Mean annual rainfall & 0.891 & 0.060 \\
\hline
\end{tabular}

*Shows the change is significant at 0.05

As it is observed from Figure 3, for any unit time increment the mean annual rainfall depicts a 3.51 decrease $(\mathrm{p}<0.05)$. The mean annual rainfall temporal distribution shows a smooth cyclic sequence signifying that this period has relatively similar rainfall records. Although it is not significant, the rainfall pattern of the area for the period 1987 to 2005 shows an increasing trend.

The peak flow shows significant lessening from the period 1976 to 1978 and a beat constant pattern from 1979 to 1982 , where as the rest years show relative ups and downs which are somewhat mirror images of one to the other $(\mathrm{p}<0.05)$.

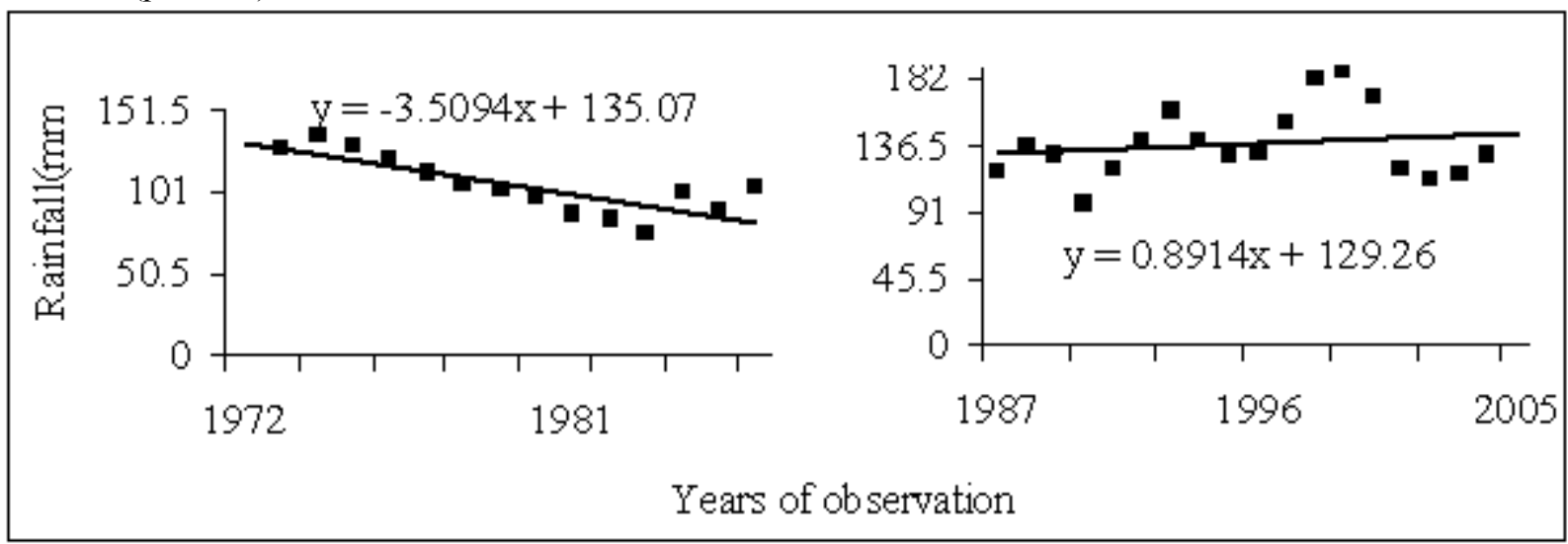

Figure 4: Linear trend of mean annual rainfall in the two periods

It decreases by 0.26 magnitudes for a unit time increment with an irregular cyclic trend (Figure 5). This reduction in high flow trend of the area is suspected as a consequence of the decrease in the rainfall condition of the area since the rainfall pattern of the area also showed a similar decreasing trend in this period. In contrary to the first period, peak flow in the year 1987 to 2005 reveals an insignificant increasing trend with a relatively smooth annual cyclic sequence $(\mathrm{p}>0.05)$. Farquharson and Sutcliffe $(1998)$ noted that temporal variability and occasional periodicity of sub-Saharan African river flows are primarily induced by temporal and inter-temporal rainfall variability. Besides, Yilma and Demare (1995) found out that rainfall variability in the Ethiopian and Eritrean highlands significantly affected the flow regimes of the Blue Nile River. These reports imply the corresponding effect of rainfall on the flow process of the river in time series. 


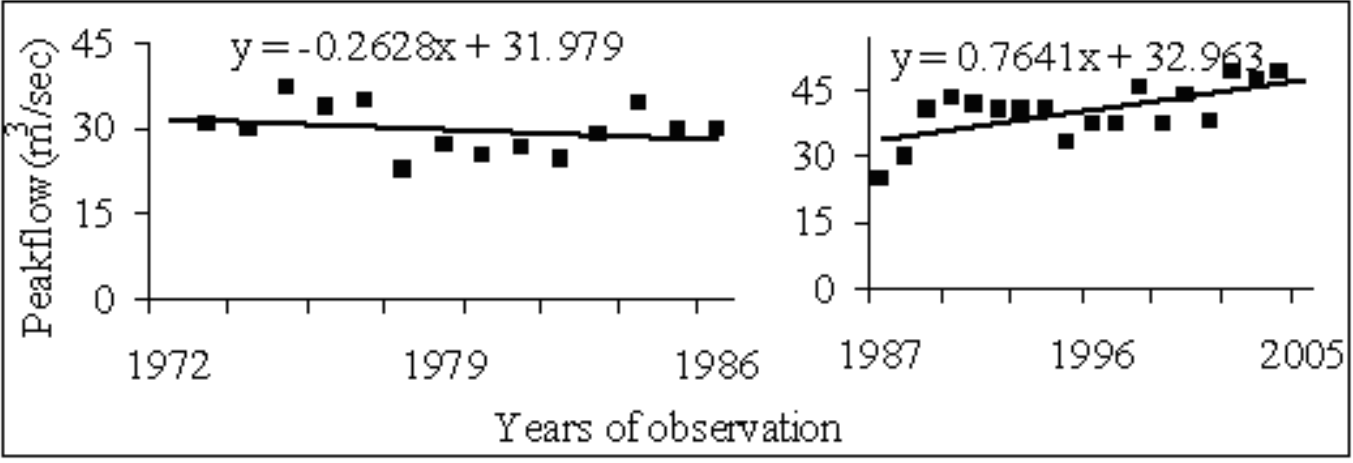

Figure 5: Linear trend of annual peak flow in the two periods

3.3.2 Changes in wet and dry season flow for 1972 to 1986 period

Though the magnitude is different, an increasing trend in both wet and dry seasons' total flow was occurred in this period (Figure 6). Separately, the total flow of the wet season was increased by the rate of 0.44 per annum while that of the dry seasons flows by 0.27 . However, the regression analysis showed as this increasing trend is not significant $(\mathrm{p}>0.05)$.

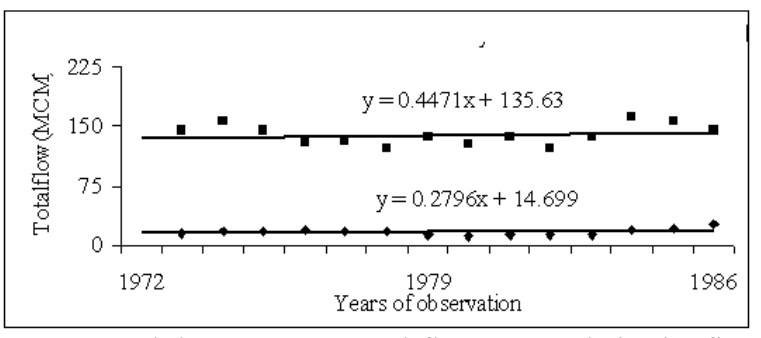

Figure 6: Wet and dry seasons' total flow trends in the first period

Base flow reveals contradiction in the two seasons flow for the period 1972 to 1986 . Even if it is insignificant ,base flow was increased by 1.13 annual rate in the wet seasons while its dry season flow pattern showed a decreasing tendency by 0.058 annual rate $(\mathrm{p}<0.05)$ (Figure 7$)$.

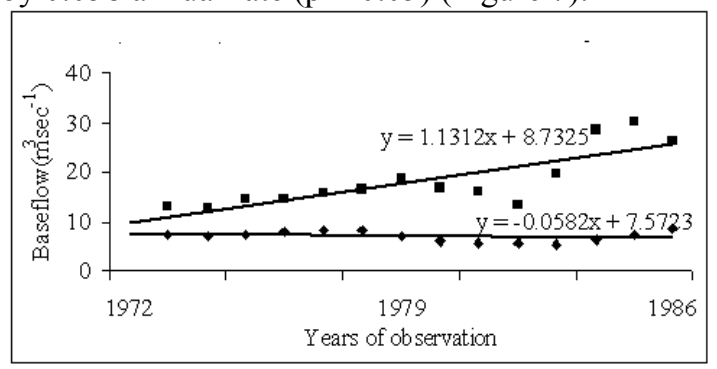

Figure 7: Wet and dry seasons' base flow Variation in the first period

\subsubsection{Changes in wet and dry seasons flow for 1987 to 2005 period}

Similar to that of the first period, the total flow pattern of the wet period showed an increasing trend with an annual rate of 3.21. But, the dry season flow showed a decreasing trend with a rate of $0.31(\mathrm{p}<0.05)$. As it is illustrated in Figure 15, the slope of the linear trend line rises steeply in the period 1995 to 1998. This contradictory result of total flow pattern in the two seasons is suspected as it may be the consequences of seasonal rainfall variation. This assumption is dependent on the correspondence between these two variables which was noticed from their 3-years moving average graph. The wet period base flow pattern still showed an insignificant increasing trend with nearly 1.1 annual rate; while it continued its significant dry season decrease by the rate of 0.21 for the period 1987 to 2005 (Figure 9). This shows the base flow which was contributed from the ground water subsequently decreases throughout the study period indicating that there is a considerable exhaustion in ground water recharge potential.

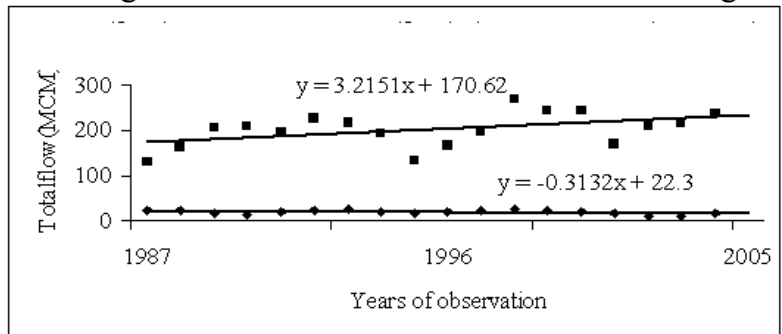

Figure 8: Wet and dry seasons' variation of total flow in the second period 
Similarly, Tadele and Gerd (2009) have investigated a wet period stream flow increase and a dry season decrease of stream flow in Hare Watershed. Additionally, Woldeamlak (2003) reported a statistically significant dry season stream flow decrease in Chemoga watershed. Generally, this time series analysis of rainfall and stream flow patterns in the area depicts as there is a corresponding seasonal and periodic variations in rainfall and streamflow.

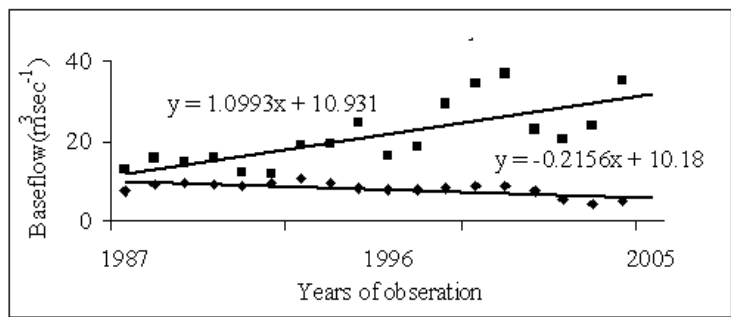

Figure 9: Wet and dry seasons' change of base flow in the second period

In contrast to the seasonal fluctuation in the trends of the hydrologic variables, analysis on their annual trend showed a continuous increasing trend in rainfall, total flow and peak flow components. On the other hand, the base flow component of the river reveals a decreasing trend throughout the study period (1972 to 2005) (Figure 10). Table 3: Summary statistics for annual hydrologic change observation in 1972 to 2005

\begin{tabular}{llcc}
\hline Period & Variables & \multicolumn{2}{c}{ Parameters } \\
\cline { 3 - 4 } & & Slope & p-Values \\
$1972-2005$ & Rainfall & 1.366 & $0.006^{*}$ \\
& Total flow & 3.530 & $0.002^{*}$ \\
& Peak flow & 0.597 & $0.004^{*}$ \\
& Base flow & -0.047 & $0.001^{*}$ \\
\hline
\end{tabular}

The statistical analysis also reveals that the change is significant (Table 3). The reduction in base flow component of the river with the presence of an increasing rainfall for the area creates a pressure to think as there should be other factors which brings this exhaustion of the ground water in recharging the river. A tremendous rise in peak flow pattern of the river associated with a continuous increase in the rainfall is the other frightening observation from this time series analysis.

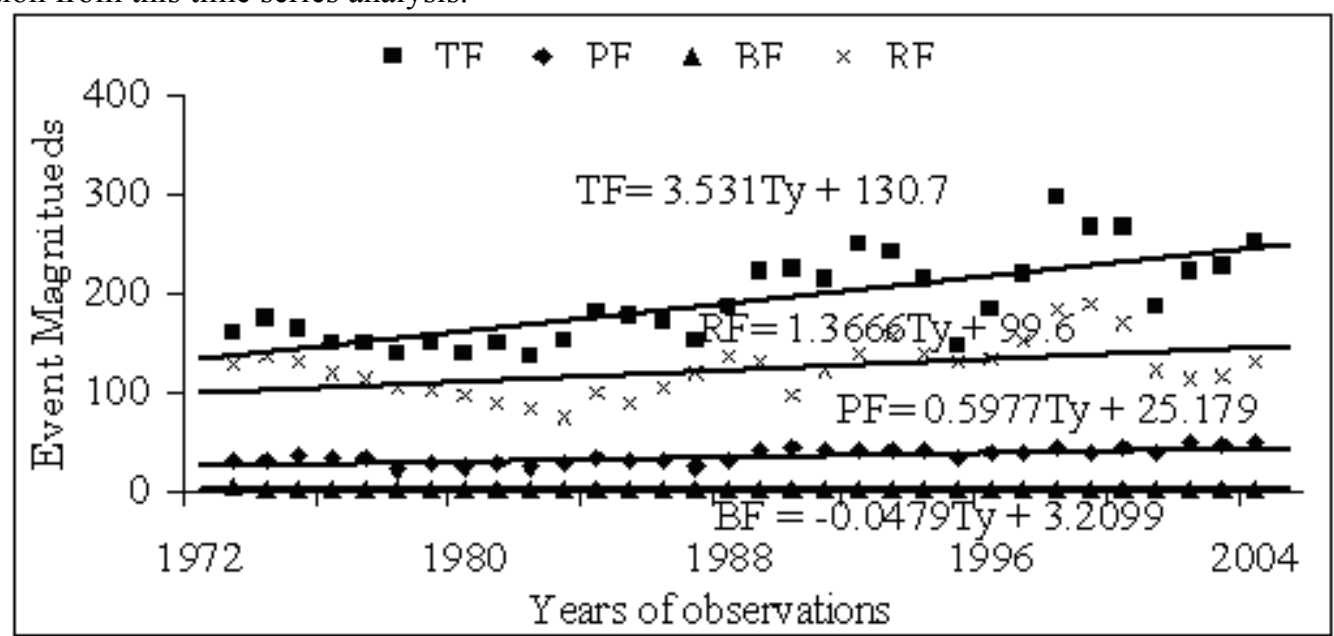

Figure 10: Trend in Rainfall and Stream flow Components for 1972 to 2005 period

Note: $\mathrm{TF}=$ Total flow, $\mathrm{PF}=$ Peak flow, $\mathrm{BF}=$ Base flow, $\mathrm{RF}=$ Rainfall and $\mathrm{Ty}=$ Time in years

\section{Conclusion and Recommendation}

The rainfall pattern of the area does not show any significant variation for the whole study period. But the stream flow components of Neshi watershed show quantitative variations. Importantly, an increasing trend in both total and peak flow components of the river is observed. In contrast to this, the result reveals a continuous reduction in base flow component of the river for both time series. Generally, the result confirms that the base flow is continuously decreased. Overall, the result demonstrates as the sustainability of water yield from the area is largely threatened. Basically, a stream flow irregularity in Neshi watershed was observed. Analysis of community knowledge and studies of socio-economic circumstance are basic in filling the gap in the physical data analysis and for revealing the extent of impacts on livelihood. In the future, these issues need due consideration and research works in Neshi watershed. Furthermore, a research which uses forest hydrology related model is worthwhile to be carried out in order to have a more elaborative and future forecasting result about the change in water yield 
potential of the area related with more complex catchment characteristics.

\section{References}

Abbay River Basin Integrated Development Master Plan Project (ARBIDMPP). 1998. Phase 2, Volume III Water Resources and Hydrology, Ministry of Water resources, FDRE.

Awulachew, S. B., Matthew, M., Tammo, S. and Abdalla, A. 2008. A review of hydrology, sediment and water resource use in the Blue Nile Basin. Colombo, Sri Lanka: International Water Management Institute.87p.

Bayissa, Chala. 2007. Assessment of Malaria as a Public Health Problem in Finchaa Sugar Factory based on Clinical Records and Parasitological Surveys. MSc Thesis. Addis Ababa University, Ethiopia.

Farquharson, F.A.K. and Sutcliffe. 1998. Regional variation of African river flows. In: Servat E., Hughes, D., Fritsch, J. M. and Hulme, M. (eds), Water Resources Variability in Africa. Proceedings of the Abidjan Conference, November, 1998, IAHS paper no. 252, IAHS, Wallingford. pp161-169.

Gebrehiwot, G. S., Iistedt, U., G“ ${ }^{\circ}$ ardenas, A. I. and Bishop, K. 2010. Hydrological characterization of watersheds in the Blue Nile basin. Hydrology and Earth System Sciences Discussion, 7: 4089-4111.

Jeans, K., Noordwijk, M. V., Joshi, L., Widayati, A., Farida and Leimona, B. 2006. Rapid hydrological appraisal in the context of environmental service rewards. World Agroforestry Center. [Online]. Available from: http://www.worldagroforestrycentre.org/sea [Date accessed: 21-09-10].

Legesse, D., Vallet-Coulomb, C. and Gasse, F. 2003. Hydrological response of a catchment to climate and land use change in Tropical Africa: case study South Central Ethiopia. Journal of Hydrology, 275: 67 - 85.

Leonard, B. 2003. Land Degradation in Ethiopia: Its extent and Impact. Commissioned by the government with World Bank support.

Seleshi, Bekele Awulachew, Aster, Denekew Yilma, Makonnen, Loulseged, Willibald, Loiskandl, Mekonnen, Ayana and Tena, Alamirew. 2007. Water Resources and Irrigation Development in Ethiopia. Colombo, Sri Lanka, IWMI. 82p.

Tadele, K. and Gerd, F. 2009. Impact of Land Use / Cover Change on Streamflow: The Case of Hare River Watershed, Ethiopia. Catchment and Lake research, 80-85.

Woldeamlak, Bewket. 2003. Towards integrated watershed management in highland Ethiopia: the Chemoga watershed case study. PhD Thesis, Wageningen University and Research Centre.176p.

Yilma, S. and Demaree, G.R. 1995. Rainfall variability in the Ethiopian and Eritrean highlands and its links with the southern oscillation index. Journal of Biogeography, 22: 945-946. 